\title{
DOE/ER/61459--003
}

Press Oliver W.

August 4, 1994

DOE Grant Renewal Application

Sponsor: Department of Energy

Sponsor's No: DE-FG06-92ER61459

Project Dates: 7/1/92-10/31/95

Next Funding Period: 11/1/94-10/31/95

\section{Improved Radioimmunotherapy of Hematologic Malignancies}

\section{Progress Report:}

This interim progress report summarizes our experimental results obtained during the time interval from November 1, 1993 through October 31, 1994:

Aim 1: To study the rates of endocytosis, intracellular routing, and metabolic degradation of radiolabeled monoclonal antibodies (RAbs) targeting tumor associated antigens on human leukemia and lymphoma cells.

We have recently published an article entitled "Retention of B Cell-Specific Monoclonal Antibodies by Human Lymphoma Cells" (in Bloed 83: 1390-1397; March, 1994) in which we analyzed the rates of internalization, intracellular metabolism, and shedding of 125 I-labeled monoclonal antibodies recognizing the $\mathrm{CD} 19, \mathrm{CD} 20, \mathrm{CD} 37$, CD45, and surface IgM antigens on lymphoma cells obtained from biopsies of patients with relapsed Non-Hodgkin's Lymphomas. Cell suspensions pulse-labeled with relevant antibodies were examined by cell binding assays, immunoelectron microscopy, sodium dodecyl sulfate polyacrylamide gel electrophoresis, and thin layer chromatography. 125Ianti-CD45 antibodies (e.g. BC8) were stably retained on the surface of lymphoma cells without appreciable degradation, whereas 125 I-labeled anti-IgM, anti-CD 19, and antiCD22 antibodies were rapidly internalized by cells and metabolized as summarized in Table I below.

Table I

Comparative Metabolism of Antibodies Targeting B Cell Surface Antigens

$\%$ of Total CPM Released to Supernatant in

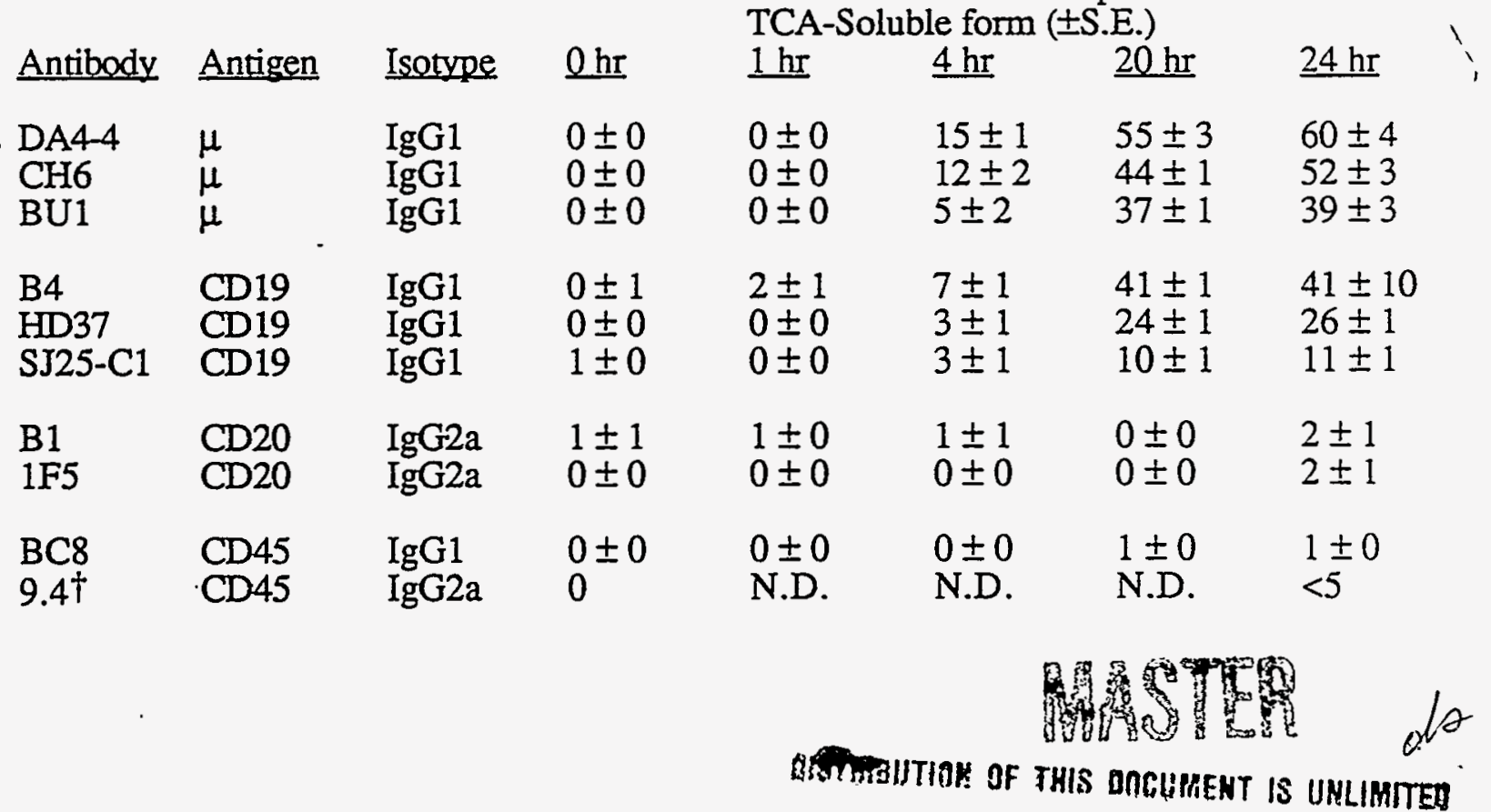




\section{DISCLAIMER}

This report was prepared as an account of work sponsored by an agency of the United States Government. Neither the United States Government nor any agency thereof, nor any of their employees, makes any warranty, express or implied, or assumes any legal liability or responsibility for the accuracy, completeness, or usefulness of any information, apparatus, product, or process disclosed, or represents that its use would not infringe privately owned rights. Reference herein to any specific commercial product, process, or service by trade name, trademark, manufacturer, or otherwise does not necessarily constitute or imply its endorsement, recommendation, or favoring by the United States Government or any agency thereof. The views and opinions of authors expressed herein do not necessarily state or reflect those of the United States Government or any agency thereof. 


\section{DISCLAIMER}

\section{Portions of this document may be illegibie in electronic image products. Images are produced from the best available original document.}


The data in the preceding table were compiled from four separate experiments performed by incubating 106 Ramos Burkitt's lymphoma cells (in triplicate) with 200,000 c.p.m. of I-

125 labeled antibodies for $0,1,4,20$, or $24 \mathrm{hr}$ and then analyzing cell surface, intracellular, and supernatant radioactivity. The TCA soluble cpm released to the supernatant are

presented as the means \pm standard errors. The comparative retention of 125 I-labeled anti-B cell antibodies is shown in Figure 1 below:

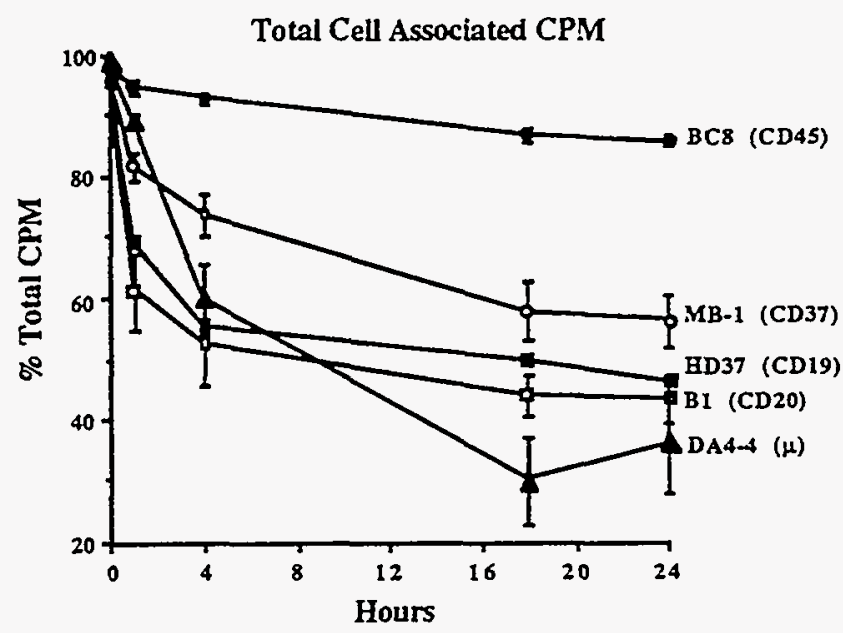

Figure 1: Retention of 125I-labeled antibodies by human B cell lymphomas. Lymphoma cell suspensions were labeled with $125 \mathrm{I}$-labeled antibodies for 45 minutes at $4^{\circ} \mathrm{C}$, washed and then incubated at $37^{\circ} \mathrm{C}$ for $0,1,4,18$, or $24 \mathrm{hr}$ before analyzing for cell associated radioactivity. The data are presented as the \% of initially bound cpm retained by cells. Data for all twelve parients were averaged and plotted with standard error bars.

The results of these studies suggest that antibodies which are slowly internalized and degraded (e.g. the anti-CD20 MAb B1 and the anti-CD45 MAb BC8) are best suited for radioimmunotherapy, whereas rapidly internalized antibodies (e.g. the anti-CD19 antibody $\mathrm{HD} 37$ and the anti-CD22 antibody HD6) are most appropriate for applications as immunotoxins.

Aim 2. To examine the effects of maximally tolerated doses of lysosomotropic amines (e.g. chloroquine), carboxylic ionophores (liposomal monensin), and thioamides (propylthiouracil) on radioimmunoscintigraphy and radioimmunotherapy in an in vivo tumor xenograft system.

We have previously published our findings demonstrating that ammonium chloride, amantadine, chloroquine, monensin, nigericin, propylthiouracil, and verapamil can all retard the intracellular metabolism of 125 I-labeled antibodies in vitro, thereby augmenting the retention of radioimmunoconjugates by tumor cells (Press OW, DeSantes KD, Anderson SK, and Geissler F. Inhibition of catabolism of radiolabeled antibodies by tumor cells using lysosomotropic -amines and carboxylic ionophores. Cancer Res. 50: 12431250,1990 .). Our attempts to extend these promising results with cell suspensions to mouse models have been hampered to date by the occurrence of serious toxic effects such as diarrhea, weight loss, and severe wasting. We are continuing attempts to identify vehicles and schedules which will make the administration of these agents in vivo feasible, or to identify less toxic congeners for clinical applications. 
Aim 3. To examine the impact of newer radioiodination techniques (tyramine cellobiose) on the metabolic degradation of radioiodinated antibodies, and on the radioimmunoscintigraphy and radioimmunotherapy of neoplasms.

We have recently submitted a manuscript entitled "Tyramine cellobiose (TCB) antibody radioiodination: Pre-clinical studies for leukemia therapy" summarizing the synthesis and preliminary analysis of an anti-CD33 monoclonal antibody (P67) radioiodinated with either conventional chloramine $\mathrm{T}$ or novel tyramine cellobiose conjugation methods" demonstrating the superiority of immunoconjugates synthesized with the TCB method compared with conventional chloramine $\mathrm{T}$ iodination. In vitro experiments show that only $38 \%$ of the radioiodine on P67 labeled by chloramine T remained associated with cells after 24 hours of incubation while $72 \%$ of the TCB labeled radioiodine remained cell-associated. Biodistribution experiments in mouse tumor models coninjected with CT or TCB labeled P67 also showed an increased tumor concentration and retention of the TCB conjugates with a 4.5 fold greater retention as assessed by an area under the curve $(\% \mathrm{DD} / \mathrm{gram}$ vs. time analysis). Concentrations of radioiodine in other tissues were comparable for both TCB and CT labels except in the liver where TCB was twice that of CT.

A summary of the biodistribution data for P67 in the HEL tumor xenograft system in nude mice is shown below for the two labeling methods at the 48 . hour time point:

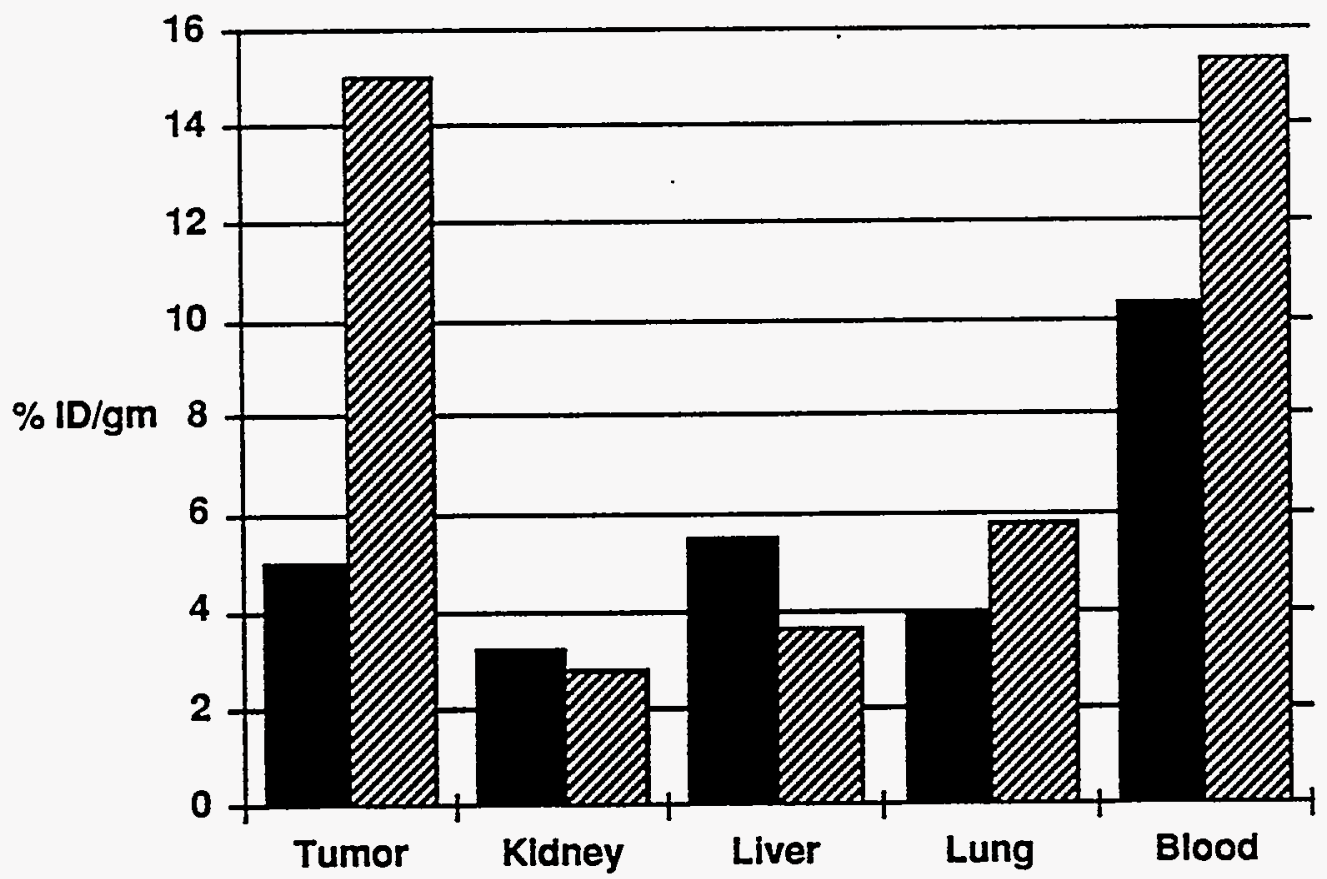

Figure 2: Comparative Biodistributions of Chloramine $T$ (CT in black) and Tyramine Cellobiose (TCB, hatched) labeled 125I-P67 (anti-CD33) antibody in nude mice bearing Human Erythroleukemia (HEL) tumor xenografts 48 hours after antibody injection.

Aim 4. To compare the endocytosis, intracellular routing, and degradation of radioimmunoconjugates prepared with - different radionuclides (131Iodine, 111Indium, 90Yttrium, 99m Technetium, 186Rhenium).

We are preparing a manuscript for publication comparing the internalization, intracellular routing, metabolism, and retention of radioimmunoconjugates radioiodinated 
with the Iodo-Gen method with antibodies conjugated to radiometals (e.g. Indium-111, yttrium 90) using a macrocycle chelate (12N4-maleimide from American Cyanamid \& Celltech). Our unpublished results suggest that tumor cells degrade and exocytose Indium111-anti-CD33 radioimmunoconjugates more slowly than the corresponding radioiodinated conjugates, resulting in enhanced retention of radioactivity by tumor cells targeted with immunoconjugates binding to internalizing antigens.

Aim 5. To examine the utility of radioimmunoconjugates targeting oncogene products for the radioimmunotherapy and radioimmunoscintigraphy of cancer.

As suggested by the reviewers of our grant and as mandated by funding cuts in the requested budget, we have focused our research efforts on Aims 1-4 and have reserved work on Aim 5 until additional funds are available.

\section{Recent Publications supported by this grant:}

1. Press OW, Howell-Clark J, Anderson S, Appelbaum FR, and Bernstein ID. Retention of Antibody Conjugates by Human Lymphoma Cells, Blood 83:1390-1397, 1994.

2. Press OW, Eary J, Appelbaum FR, Martin PJ, Badger CC, Nelp WB, Glenn S, Butchko G, Fisher D, Porter B, Matthews D, Fisher L, and Bernstein ID. Radiolabeled Antibody Therapy of B Cell Lymphomas with Autologous Bone Marrow Support, New England Journal of Medicine 324:1219-1224, 1993.

3. Press OW, Eary J, Appelbaum F, Badger C, and Bernstein I. "Radioimmunoconjugate therapy of malignant lymphomas". In Malignant Lymphomas (Bruce Dana, ed.), Kluwer Academic Publishers, Boston, pp 127-145, 1993.

4. Press OW, Eary J, Appelbaum F, and Bernstein I. "High dose radioimmunotherapy with marrow transplantation". In Immunoconjugate Therapy of Hematologic Malignancies (Steven Rosen, ed.), Kluwer Academic Publishers, pp. 13-22, 1993.

5. Press OW, Eary J, Appelbaum F, and Bernstein I. High Dose Radioimmunotherapy with Autologous Bone Marrow Transplantation for Malignant Lymphomas. In Cancer Therapy with Radiolabeled Antibodies (D. Goldenberg, ed.), CRC Press Inc. (in press), 1994.

6. Press, OW, Eary, JF, Appelbaum, FR, and Bernstein, I. Radiolabeled antibody therapy of lymphomas. In Biologic Therapy of Cancer Updates. (eds. DeVita, V., Helliman, S., and Rosenberg, S.A.), Vol. 4 (\#4): J.B. Lippincott Co., Philadelphia, pp 1-13, 1994.

7. Press OW, Eary JF, Appelbaum FR, and Bernstein ID. Monoclonal Antibody Targeting of Radioactive Isotopes for Relapsed Lymphomas. In Technical and Biological Components of Marrow Transplantation (C.D. Buckner, ed.), Kluwer Academic Publishers, (In Press), 1994.

Manuscripts submitted:

1. Eary J, Venkatesan P, Krohn K, Press O, Badger C, Bernstein I, and Nelp W. Enhanced retention of tyramine cellobiose radioimmunoconjugates by tumor cells (in preparation).

2. Shan $\mathrm{D}$ and Press $\mathrm{O}$, Constitutive Endocytosis and Metabolism of CD22 by Human $B$ Cell Lines, (in preparation). 
Manuscript in Preparation

1. Press $\mathrm{O}$ and Bilge A, Immune Conjugates in Immunotherapy, in Handbook of Experimental Immunology (T. J. Kipps, ed.), Blackwell Scientific Publications, (in preparation).

Abstracts Presented:

1. Press OW, Eary JF, Badger CC, Martin PJ, Appelbaum FR, Nelp WB, Fisher DR, Matthews D, and Bernstein ID. Radiolabeled antibody therapy of B cell lymphomas. J. Cellular Biochem, Suppl 17E, p. 271, 1993.

2. Press OW, Eary JF, Martin PJ, Appelbaum FR, Glenn SD, Butchko GM, Matthews DC, Bernstein ID. Phase I and II trials of Iodine-131-labeled anti-CD20 (B1) antibody therapy for relapsed B cell lymphomas, Blood 82 (Suppl. 1): 333a, 1993.

3. Press OW, Eary JF, Martin PJ, Appelbaum FR, Glenn SD, Butchko GM, Matthews DC, Berstein ID. Radioimmunotherapy of B cell lymphomas with Iodine-131-labeled antiCD20 (B1) monoclonal antibodies, Proceedings of the 8th NCI-EORTC Symposium on New Drugs in Cancer Therapy. Annals of Oncology 5 (Suppl. 5): 70, 1994.

4. Press O, Eary J, Martin P, Appelbaum FR, Glenn S, Butchko G, Matthews D, and Bernstein I, Radiolabeled antibody therapy of lymphomas. Can. I. Physiology and Pharm. 72 (Suppl. 1): 491994.

\section{RESEARCH PLANS FOR 1993-1994}

No changes from the initial application.

\section{BUDGET JUSTIFICATION (for 11/1/93 to 10/31/94)}

1. Personnel costs

A. Dr. Oliver Press (Principal Investigator) will increase his effort on this grant from 20 to $25 \%$ to allow assumption of the supervisory duties of Susan Anderson, who formerly was a key participant in this project and who recently resigned.

B. Conception Warner (60\% effort) and Janet Howell-Clark (30\% effort) are laboratory technicians who are job-sharing and have been reassigned to this project to perform the antibody purification, conjugations, autoradiography, gel electrophoresis, HPLC and flow cytometry which were formerly performed by Susan Anderson, who resigned.

C. Daming Shan is a graduate student who will work on the comparative internalization of radioimmunoconjugates.

D. Fringe Benefits - University of Washington fringe benefit rates for are $22 \%$ for faculty, $30 \%$ for technicians, and $9 \%$ for graduate students.

2. Equipment: None requested.

3. Other Direct Costs:

$$
\text { Budget removed. do }
$$

A. Supplies - These experiments require extensive cell culture work and will consume large volumes of media and fetal calf serum. The supplies expenses listed are minimal estimates, and represent an overall decrease in requested supply funds from last year necessitated by the inflation of salaries. 